\title{
Effectiveness of Interactive Media Based on Flash Player and Video on Napkin Folding Material
}

\author{
Yeni Yulianti ${ }^{1}$, Annis Kandriasari $^{2}$, Nur Riska ${ }^{3}$ \\ \{yeni.yulianti@unj.ac.id ${ }^{1}$, annis@unj.ac.id²,nrtadjoedin@unj.ac.id ${ }^{3}$ \} \\ Culinary Arts Vocational Education Study Program, Universitas Negeri Jakarta, Indonesia ${ }^{123}$
}

\begin{abstract}
The purpose of this research was 1) to measure the feasibility of developing interactive media based on flash player and video on napkin folding material and 2) to analyze the effectiveness through increasing student learning outcomes towards the use of interactive media. The research subjects were students of culinary art - FT - UNJ. Data analysis used two ways, namely qualitative analysis and quantitative analysis (t-test). The field group trial obtained was $84.38 \%$ and entered into the "eligible" criteria. Media is declared "feasible" based on the student's ability to use interactive media about napkin folding as a learning medium for basic courses on field administration. The results of the analysis of $t$ count and t table $(8,849>1,697)$ means that the value of student learning outcomes using interactive learning media based on flash player and video on napkin folding material is greater than student learning outcomes using power point media. The calculation of the effectiveness of the experimental group using interactive media about napkin folding resulted in $88 \%$ of the high product effectiveness criteria. So, it can be concluded that interactive multimedia based on flash player and video has a positive effect on its use.
\end{abstract}

Keywords: Flash Player; Folding Material; interactive media

\section{Introduction}

The rapid development of technology has positive and negative impacts in various fields, especially in education. An interesting type of media help educators in delivering learning material to students. With high classroom conditions and lecturers, sometimes students are less able to focus on the material being taught. It is due to a variation method and material applied by each lecturer (Arsyad, A., 2002). According to observations on D3 (Associate Degree) students in the Culinary Art Education Study Program 2018/2019, it found that most students lacked in command and were passive on napkin folding material. In material value, $78 \%$ of students who got grades according to KKM (Minimum completeness criteria) are 18 students out of 39 students. Trianto (2010: 214) said that a class called complete learning if there is a minimum of $85 \%$ of students who get grades according to KKM (Trianto, 2010).

Moreover, student learning resources or references are still limited to modules and job sheets. The Culinary Art Education Study Program has used adobe Flash Player learning media as a resource of student learning on napkin folding material. Lecturers used guest napkin and PowerPoint learning media. PowerPoint media only used in the fundamental theory of napkin folding. It makes students less able to master guest napkin material and cannot correctly follow the fold examples given by the lecturer. 
Adobe Flash Player is one of the learning media through computers. It was chosen because the information technology facilities support the napkin folding learning process and invite students to be actively involved in the teaching and learning process. Also, Adobe Flash Player has characteristics that can increase the students' enthusiasm to learn, including movements, shapes, and attractive colors. These characteristics make students interested in the napkin folding learning process. Adobe Flash Player used to make interactive learning effectively, efficiently, and quickly accessed by students because education is required to develop science and technology rapidly. One software or applications that can increase learning motivation by using Adobe Flash C (Sofiyatul Hidayah, et.al., 2017). Madcoms also suggested that Adobe Flash CS6 is a good software used to support interactive learning. Because, interactive learning media with the Adobe Flash CS6 application can combine graphics, animation, sound, as well has the ability to interact with users (Tri Apriyani, 2015).

Based on this theory, it is expected in the selection of Adobe Flash Player to create media that improve student understanding. The results of Yenni's research (2018) on the use of audiovisual media with interactive CD types said that students would more readily accept audiovisual media because this media does not only involve one kind of sensory device but also to improve student learning outcomes (Yenni, et.al, 2018). The use of audiovisual media has several advantages including (1) the teaching and learning process in the classroom will be more exciting with interactive media, (2) students will be more creative, (3) student learning outcomes will be better, (4) students will be easier in understanding the material delivered by the teacher, and (5) lecturers and students will improve science and technology. Based on this study, the researchers focused on developing interactive multimedia-based learning media on napkin folding material by using Adobe Flash Player to create media that can improve students' understanding of Culinary Arts Vocational Education-FT-UNJ.

\section{Methodology}

According to Sugiyono, Research and Development (R\&D) is a research that aims to produce and develop products (Sugiyono, 2012). The study used R\&D by the 4D development model (Define, Design, Develop, and Disseminate). Multimedia-based learning media applied by using experimental research. This study used a random pretest-posttest control group design. The instrument is a data collection tool used in research. The question gave to material experts, media experts, and students of the Culinary Arts Vocational Education-FT-UNJ as participants or users. Field studies aimed to obtain initial data. It used observation and interview guidelines. Data analysis techniques used Content Validity Ratio (CVR) method by Lawshe. According to Azwar, the Content Validity Ratio (CVR) method called the Subject Matter Experts (SME), which states whether the items in the test are essential in the measurement objectives (Azwar, 2013). The CVR calculation results are in the form of a ratio of 0.00-1.00. In the calculation of the media expert and material experts, instruments calculated using the following formula (Sugiyono, 2016):

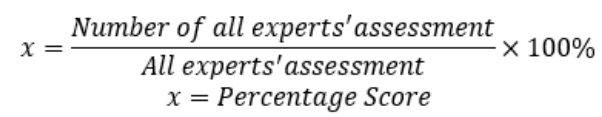

The answer results obtained by calculating the percentage score in order to develop the conclusions explained in Table 1. 
Table 1. Criteria Guidelines for Material Experts and Media Experts' Assessment

\begin{tabular}{|c|c|c|}
\hline No. & Scale & Criteria \\
\hline 1. & $0 \%-25 \%$ & There is no feasibility aspect \\
\hline 2. & $25 \%-50 \%$ & $\begin{array}{l}\text { There is a low enough feasibility } \\
\text { aspect }\end{array}$ \\
\hline 3. & $50 \%-75 \%$ & $\begin{array}{l}\text { There is a high enough feasibility } \\
\text { aspect }\end{array}$ \\
\hline 4. & $75 \%-100 \%$ & There is a high feasibility aspect \\
\hline
\end{tabular}

The answer results obtained by calculating the percentage score in order to develop the conclusions explained in Table 2.

Table 2. Criteria Guidelines for Users' Assessment

\begin{tabular}{lll}
\hline Score & & Criteria \\
\hline $\mathbf{x}>\mathbf{7 5 \%}$ & - & Feasible \\
$\mathbf{x} \leq \mathbf{7 5 \%}$ & - & Not Feasible \\
\hline
\end{tabular}

The effectiveness uses of Adobe Flash Player-based interactive media on napkin folding material development can be known by increasing children's procedural cognitive about making a variety of healthy food recipes by using the experimental design (before-after). The answer results obtained by calculating the percentage score in order to develop the conclusions explained in Table 3 (Arikunto, 2010).

Table 3. Guidelines for Product Effectiveness Criteria

\begin{tabular}{lll}
\hline No. & \multicolumn{1}{c}{ Interval } & \multicolumn{1}{c}{ Criteria } \\
\hline 1. & $76 \%-100 \%$ & High Product Effectiveness \\
2. & $51 \%-75 \%$ & Medium Product Effectiveness \\
3. & $25 \%-50 \%$ & Low Product Effectiveness \\
\hline
\end{tabular}

A hypothesis is a temporary answer to a research problem whose truth is still being empirically tested. Measurement of student learning achievement is done through post-test results. Hypothesis testing in this study used the T-test.

\section{Result and Discussion}

\section{Results of Interactive Media Development based on Adobe Flash Player}

Software specifications used in the design, manufacture, and implementation of Flashbased interactive media about napkin folding material are 1) Operating System: Windows 10 Pro; 2) Flash: Adobe Animate 2019; and 3) Video: Adobe Premiere Pro.

Table 4. Media Feasibility Assessment Results

\begin{tabular}{lllll}
\hline No & Assessment & \multicolumn{2}{l}{ Scale (percentage) } & Criteria \\
\hline 1 & Material experts' validation & $94.6 \%$ & $85.7 \%$ & high feasibility \\
2 & Media experts' validation & $85.7 \%$ & $86.4 \%$ & high feasibility \\
3 & One to one trial & $87.14 \%$ & & high feasibility \\
\hline
\end{tabular}




\begin{tabular}{llll}
\hline 4 & Small group trials & $86.31 \%$ & high feasibility \\
5 & Field group trials & $84.38 \%$ & high feasibility \\
\hline
\end{tabular}

According to the results, flash-based interactive media about napkin folding can be said to be worthy of testing on students of Culinary Arts Vocational Education-FT-UNJ. According to the material experts, flash-based interactive media about napkin folding can be said to be worthy of testing on students of Culinary Arts Vocational Education-FT-UNJ. To support the material experts' validation result, Instructional media based on interactive CD learning was said effective to improve students' outcomes because $87,60 \%$ students had reached Minimum Mastery Criteria.

Based on the result, can be concluded that instructional media based on interactive CD learning on Basic Network was effective to use as instructional media on Basic Network learning process (Doni Pernanda, et.al, 2018). Learning of multimedia inspire based interactive learning in general administration subject was valid and feasible to use as learning media in school (Nur Rahmi Akbarini, et.al, 2018). A large-scale trial conducted on the D3 (Associate Degree) of Culinary Art Vocational with 30 participants. The assessment carried out to test the feasibility of Adobe Flash Player-assisted learning media. Students asked to fill out questionnaires in order to find out their opinions about napkin folding learning media. Based on observation, the percentage results obtained $84.38 \%$ for feasible criteria. The media is declared feasible criteria based on the ability of students to use Adobe Flash Player-based interactive media about napkin folding as a learning media for basic course Culinary Art. It concluded that the implementation of napkin folding learning in large-scale trials is better than small-scale trials. Adobe Flash Player-assisted media do not need improvement.

To support the trial final product results, Addini (2016) researched the development of learning media for multimedia-based stock processing material using Adobe Flash in class X students of SMK Negeri 2 Godean. The research results of multimedia-based learning media using Adobe Flash are declared feasible as learning media by students. Each aspects' score obtained: a) 35.50 for display aspects; b) 25.69 for programming aspects; c) 35.38 for learning aspects; d) 27.84 for content aspects, ande) 124.4 for overall assessment. It means that multimedia-based learning media using Adobe Flash is feasible to use as a learning media and learning resources in SMK N 2 Godean (Addini, 2016).

\section{Results of Learning Outcomes Assessment}

There is an increase in learning outcomes in pre-test and post-test results. It can be seen from the T-test results through SPSS 16.0 program. Based on hypothesis testing results, there is a significant difference between student learning outcomes between the control group and the experimental group. The pretest results used to determine the level of difference between the two groups. The average pretest of the control group obtained 56, and the experimental group obtained 55.67. In the experimental group, there are improved learning outcomes on napkin folding material through Macromedia Flash media that obtained 32.33. In the control group, there are improved learning outcomes on napkin folding material through PowerPoint that obtained 8 .

Furthermore, the research implementation in the experimental group is done by explaining the material related to napkin folding theory through instructional media. Researchers explained and visualized the napkin folding theory through Macromedia flash media. In contrast, the control group carried out learning through PowerPoint media. According to Haviz, interactive multimedia considered suitable to deliver because it can 
involve animation, video, and audio. Also, students feel more interested in learning than using textbook media (Haviz, 2018).

The analysis shows that P-value Sig. $=0.916>0.05$. It means that Ho is accepted, and $\mathrm{Ha}$ is rejected. Tcount $0.106<\mathrm{T}_{\text {table }} 1.6715$ with degrees of freedom $=\mathrm{n} 1+\mathrm{n} 2-2=58$. It means that $\mathrm{Ho}$ is accepted, and $\mathrm{Ha}$ is rejected. The conclusion is that there is no significant difference between the pre-test results of students in the control group and the experimental group. The T-test column shows that the P-value $=0,000$ for 1 -sided tests. P-value $\mathrm{Sig}=0,000<0.05$. It means that $\mathrm{Ho}$ is rejected and $\mathrm{Ha}$ is accepted. Tcount 8,849 $<\mathrm{T}_{\text {table }} 1,6715$ with degrees of freedom $=n 1+n 2-2=58$. It means that Ho is rejected and Ha is accepted. The students' learning outcomes who used interactive learning media based on a flash player about napkin folding material is greater than PowerPoint media.

It concluded that interactive multimedia based on flash player gives a positive influence in its use. The effectiveness calculation of an experimental group that used interactive media based on a flash player about napkin folding material obtained $88 \%$ for high product effectiveness criteria. The effectiveness calculation of a control group that used PowerPoint on a flash player about napkin folding material obtained $64 \%$ for medium product effectiveness criteria. The animations, that were designed using flypaper ${ }^{\mathrm{TM}}$, were made in SWF type, so that the animations may also be added to a web page such as math learning blog support (Arifin, 2010).

The students' learning outcomes who used interactive learning media based on a flash player about napkin folding material is greater than PowerPoint media. It concluded that interactive multimedia based on flash player gives a positive influence in its use. The ability of Macromedia Flash, which can make various interesting animations, has made the software became popular in the development of interactive learning media. Some examples are the works by Luthfi \& Nafi'(Lutfi, et.al, 2011), and Safitri et al. (Safitri, et.al, 2013). Interactive learning media are not only developed by using Macromedia Flash but also by using any other computer software, some example works are by (Korakakis et al., 2009) who develop an interactive computer application to support the learning process for students in the 8th grade (Khalid et al., 2010) committed a study to know the effect of work group method and interactive learning media in algebra learning of engineering students, another work was also done by Lee et al. that made interactive multimedia modules in electrochemistry learning and it was aimed to see the effect of the developed modules toward the students' understanding and learning motivation (Lee, T, et.al, 2012).

The effectiveness calculation of an experimental group that used interactive media based on a flash player about napkin folding material obtained $88 \%$ for high product effectiveness criteria. The effectiveness calculation of a control group that used PowerPoint on a flash player about napkin folding material obtained $64 \%$ for medium product effectiveness criteria. Based on the evaluation of the experts and the perceptions of the students, the interactive learning media which has been developed was valid, practical, and highly recommended to be used as a source of student $19 \mathrm{~s}$ self-learning in discrete method courses, the interactive learning media which has been developed was effective to increase students 19 learning outcome (Faruk, 2014).

Based on the discussion above, it concluded that using visual media on napkin folding material can improve student learning achievement. Students more easily understand the material delivered by lecturers using interactive multimedia based on Adobe Flash Player. It can be seen by the students' enthusiasm for taking napkin folding material with interactive multimedia based on Adobe Flash Player. Lecturers using interactive multimedia Macromedia 
flash will save time and energy in their delivery, and the lecturers can more efficiently deliver material that is accompanied by images and animations.

\section{Conclusion}

Based on the research and development results, the following conclusions can be drawn: (1) The feasibility test results from media and material experts categorized interactive multimedia-based learning media on napkin folding material into high feasibility aspect criteria; (2) The user's assessment result obtained feasible criteria based on the ability of students to use Adobe Flash Player-based interactive media about napkin folding as a learning media for basic course Culinary Art; (3) Tcount $8,849<\mathrm{T}_{\text {table }} 1,6715$ means that the students' learning outcomes who used interactive learning media based on a flash player about napkin folding material are greater than PowerPoint media. It concluded that interactive multimedia based on flash player gives a positive influence in its use; (4) The effectiveness calculation of an experimental group that used interactive media based on a flash player about napkin folding material obtained $88 \%$ for high product effectiveness criteria. The effectiveness calculation of a control group that used PowerPoint on a flash player about napkin folding material obtained $64 \%$ for medium product effectiveness criteria.

\section{Acknowledgment}

The author would like to say thank the Faculty of Engineering who has funded the research through the BLU fund of independent research. Moreover, the author would like to thank their colleague for their contribution and support to the research, also thank all the reviewers who gave valuable inputs to the manuscript and helped in completing the paper.

\section{References}

[1] Addini, Nirmala. (2016). Pengembangan Media Pembelajaran Materi Mengolah Stock Berbasis Multimedia Menggunakan Adobe Flash Pada Siswa Kelas X Smk Negeri 2 Godean. Thesis. https://eprints.uny.ac.id/44552/

[2] Apriyani, Tri. (2015). Pengembangan Media Pembelajaran Interaktif Adobe Flash CS6 Untuk Meningkatkan Keterampilan Membaca Teks Pendek Bahasa Perancis Siswa Kelas XI SMA El Shadai Magelang. Universitas Negeri Yogyakarta. 2015, p. 32:194

[3] Arifin S., Zulkardi, and Darmawijoyo. (2010). Pengembangan Blog Support Pembelajaran Matematika Sekolah Menengah Atas. Jurnal Pendidikan Matematika. 2010. 4 (2): 70-85

[4] Arikunto, Suharsimi. (2010). Prosedur Penelitian Suatu pendekatan Praktek (Jakarta: Rineka Cipta)

[5] Arsyad, A. (2002). Media Pembelajaran (Jakarta: Raja Grafindo Persada)

[6] Azwar Saifuddin. (2013). Metode Penelitian (Yogyakarta: Pustaka Pelajar)

[7] Doni Pernanda, Mahesi Agni Zaus, Rizky Ema Wulansari, Syaiful Islami. (2018). Effectiveness of instructional media based on interactive cd learning on basic network at vocational high school : improving student cognitive ability. Proceeding: International Conferences on Educational, Social Sciences and Technology. Publisher: Fakultas Ilmu Pendidikan UNP ISBN (Print): 978-989-758-296-7. ISBN (Electronic): 978-602-73537-9-4 Published April 2018. https://www.gci.or.id/proceedings/view_article/63/1/icesst-2018

[8] Faruk, Alfensi. (2014). Development of Interactive Learning Media Based Lectora Inspire in Discrete Method Course. In: International Conference on Research, Implementation and Education of Mathematics and Sciences 2014, 18-20 May 2014, Yogyakarta, Indonesia. Avaliable from : http://eprints.unsri.ac.id/4803/ 
[9] Khalid, M. S., Alias, M., Razally, W., Yamin, S., \& Herawan, T. (2010). The Influence of Teamwork Using a Multimedia Interactive Courseware in Learning Pre-Algebra. Procedia Social and Behavioral Sciences 8: 654-662.

[10] Korakakis, G., Pavlatou, E. A., Palyvos, J. A., \&Spyrellis, N. (2009). 3D visualization types in multimedia applications for science learning: A case study for 8th grade students in Greece. Computers \& Education 52(3): 390-401.

[11] Lee, T. T.,\&Osman, K.. (2012). Interactive multimedia module in the learning of electrochemistry: effects on student's understanding and motivation. Procedia - Social and Behavioral Sciences 46: 1323 - 1327.

[12] M Haviz. (2018). Computer-assisted Biology Learning Materials: Designing and Developing an Interactive CD on Spermatogenesis. IOP Conference Series: Materials Science and Engineering, Volume 335, The 2nd International Conference on Mathematics, Science, Education and Technology 5-6 October 2017, Padang, West Sumatera, Indonesia. https://iopscience.iop.org/article/10.1088/1757-899X/335/1/012081/meta

[13] Nur Rahmi Akbarini, Wiedy Murtini, Andre N Rahmanto. (2018). Design of Interactive Learning Multimedia Development in General Administration Subject. Vol 5. No 4 (2018). International Journal of Multicultural and Multireligious Understanding. ISSN : 2364-5369. DOI: http://dx.doi.org/10.18415/ijmmu.v5i4.218 Avaliabel from : https://ijmmu.com/index.php/ijmmu/article/view/218

[14] Lutfi, K., \& Nafi', M. (2011). Interactive Multimedia Based Learning Media For Javanese Letters Using Macromedia Flash 8. Available from : http://eprints.uny.ac.id/id/eprint/5965

[15] Safitri, M., Hartono, Y., \& Somakim. (2013). Development Of learning media Based Macromedia Flash About Triangle For Student Grade 7 Junior High School. Proceeding The First South East Asia Design/Development Research (SEA-DR) International Conference. Palembang: 22-23 April 2013. Palembang: 241-250.

[16] Sofiyatul Hidayah, Sri Wahyuni, Hety Mustika Ani. (2017). Penggunaan media pembelajaran interaktif dengan Aplikasi adobe flash cs6 untuk meningkatkan motivasi Belajar pada kompetensi dasar menganalisis peran, fungsi Dan manfaat pajak (studi kasus siswa kelas xi ips 1 man 1 jember Semester genap tahun ajaran 2016/2017). Jurnal Pendidikan Ekonomi: Jurnal Ilmiah Ilmu Pendidikan, Ilmu Ekonomi, dan Ilmu Sosial Volume 11 No 1.

[17] Sugiyono. (2012). Metode Penelitian Kuantitatif, kualitatif dan R \& D (Bandung:Alfabeta).

[18] Sugiyono. (2016). Metode Penelitian Kuantitatif, Kualitatif dan R\&D (Bandung: PT Alfabet)

[19] Trianto. (2010). Model Pembelajaran Terpadu, Konsep, Strategi dan Implementasinya dalam KTSP (Jakarta: Bumi Aksara)

[20] Yenni, Syamswisna, Reni Marlina. (2018). Pengaruh Media Pembelajaran Audiovisual Terhadap Hasil Belajar Siswa Materi Sel Kelas Xi Mia SMA. Jurnal Pendidikan Dan Pembelajaran Khatulistiwa Volume Issue http://jurnal.untan.ac.id/index.php/jpdpb/article/viewFile/27915/75676578090 